\title{
Remedial Principles and Meaningful \\ Engagement in Education Rights \\ Disputes
}

\section{S Liebenberg*}

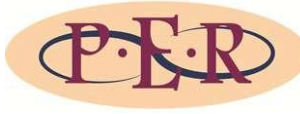

Author

Sandra Liebenberg

\section{Affiliation}

Human Rights Law,

University of Stellenbosch

Law Faculty, South Africa

Email sliebenb@sun.ac.za

Date published 25 April 2016

\section{Editor Prof C Rautenbach}

How to cite this article

Liebenberg S "Remedial

Principles and Meaningful

Engagement in Education

Rights Disputes" PER / PELJ

2016(19) - DOI

http://dx.doi.org/10.17159/1727 -3781/2016/v19i0a739

\section{Copyright}

This work is licensed under a Creative Commons Attribution 4.0 International License.

DOI

http://dx.doi.org/10.17159/1727 -3781/2016/v19i0a739

\begin{abstract}
This article evaluates the meaningful engagement doctrine in the education rights jurisprudence of the Constitutional Court in the light of a set of normative principles developed by Susan Sturm for evaluating participatory public law remedies. It commences by identifying four principles for evaluating participatory remedies appropriate to South African constitutional law and jurisprudence. Thereafter the relevant jurisprudence is analysed and evaluated in the light of these principles. The article concludes by making proposals for the development of meaningful engagement as a participatory remedy in educational rights disputes. These proposals seek to ensure a better alignment between the meaningful engagement remedy and the four remedial principles identified.
\end{abstract}

\section{Keywords}

Meaningful engagement; constitutional education rights; school governance; public law remedial principles; participatory remedies; supervisory orders; Susan Sturm. 


\section{Introduction}

In Fose v Minister of Safety and Security ${ }^{1}$ (Fose), the Constitutional Court encouraged the Courts to be creative and innovative in crafting remedial tools to ensure the effective vindication of constitutional rights. Courts have a responsibility to craft effective remedies when the legal process establishes an infringement of constitutional rights, particularly in a context "where so few have the means to enforce their rights through the courts."2

The need for remedial innovation is particularly acute in the context of school governance disputes which implicate the complex set of educational rights entrenched in section 29 of the Constitution. ${ }^{3}$ Such disputes have brought into sharp relief the tensions between redressing the legacy of apartheid education, ${ }^{4}$ on the one hand, and respecting the integrity of local school governance, on the other. ${ }^{5}$

Three significant educational rights judgments of the Constitutional Court Head of Mpumalanga Department of Education v Hoërskool Ermelo 6 (Hoërskool Ermelo), Head of Department, Department of Education, Free State Province $v$ Welkom High Schoo/ (Welkom High School), and MEC for Education $v$ Governing Body of the Rivonia Primary Schoo/ ${ }^{\beta}$ (Rivonia

* Sandra Liebenberg, BA LLB (UCT) LLM (Essex) LLD (Wits). Distinguished Professor and H. F. Oppenheimer Chair in Human Rights Law, University of Stellenbosch Law Faculty. Email: sliebenb@sun.ac.za. I thank two anonymous referees for helpful comments received. Research funding is received from the National Research Foundation. Any opinion, findings, conclusions or recommendations expressed in this article are those of the author, and the NRF does not accept any liability in regard thereto.

1 Fose $v$ Minister of Safety and Security 19973 SA 786 (CC).

2 Fose $v$ Minister of Safety and Security 19973 SA 786 (CC) para 69.

3 Section 29 of the Constitution is a complex provision encompassing an unqualified right to basic education; a qualified right to further education; a right to receive education in the official language of one's choice in public education institutions where "reasonably practicable" taking into account a range of factors; and the right to establish and maintain, subject to various qualifications, independent educational institutions.

$4 \quad$ This tension manifests itself in steep disparities in educational access and resources between schools in formerly white and black areas. See Spaull 2012 Poverty and Privilege.

5 Woolman describes school governing bodies as emergent institutions for flexible, reflexive and experimental decision-making. As such, they promote local forms of participatory democracy. Woolman The Selfless Constitution $338-348$.

$6 \quad$ Mpumalanga Department of Education v Hoërskool Ermelo 20102 SA 415 (CC).

7 Head of Department, Department of Education, Free State Province v Welkom High School 20142 SA 228 (CC).

$8 \quad$ MEC for Education v Governing Body of the Rivonia Primary School 20136 SA 582 (CC). The Rivonia Primary School judgment was handed down by the Constitutional Court just under 3 months after the Welkom High School judgment. 
Primary School) had their origin in challenges brought by school governing bodies to interventions by provincial heads of education departments in the language, pregnancy and admission policies adopted by the respective governing bodies. The Constitutional Court emphasised the importance of engagement and cooperation between the parties as a constitutionally required approach to resolving these disputes. ${ }^{9}$ In these contexts, meaningful engagement holds promise as an innovative remedial response to constitutional infringements of the educational rights in section 29 of the Constitution and related rights in the Bill of Rights. ${ }^{10}$ However, the role of engagement at the remedial stage of these cases raises a number of questions regarding its alignment with the norms of public law remedial decision-making.

Susan Sturm has developed a sophisticated framework for assessing participatory remedies in the light of general principles applicable to public law remedies. ${ }^{11}$ Drawing on her framework, this article aims to evaluate meaningful engagement as a constitutional remedy in the context of the education rights cases referred to above. It commences by identifying a set of normative principles appropriate to evaluating participatory remedies such as meaningful engagement. It thereafter proceeds to analyse and evaluate the role which engagement has played in the three Constitutional Court judgments referred to above in the light of these remedial principles. The article concludes by making proposals for the development of meaningful engagement as a participatory remedy in educational rights disputes. These proposals seek to ensure a better alignment between the meaningful engagement remedy and the public law remedial principles discussed in part 2.

9 Meaningful engagement was pioneered in eviction disputes implicating the housing rights in section 26 of the Constitution. See, for example: Occupiers of 51 Olivia Road, Berea Township and 197 Main Street Johannesburg v City of Johannesburg 20083 SA 208 (CC); Residents of Joe Slovo Community, Western Cape $v$ Thubelisha Homes 20103 SA 454 (CC); Schubart Park Residents Association v City of Tshwane Metropolitan Municipality 20131 SA 323 (CC); Pheko v Ekhurhuleni Metropolitan Municipality 20122 SA 598 (CC).

10 The other rights affected in these disputes have primarily entailed the right against unfair discrimination (s 9(3)), the right to just administrative action (s 33), and the principle of the best interests of the child (s 28(2)).

11 Sturm 1991 The Georgetown LJ 1355. 


\section{Evaluative principles for constitutional remedies}

The courts' power to grant remedies for infringements of constitutional rights are set out in sections 38 and 172(1) of the Constitution. The former provision gives a court the power to grant "appropriate relief, including a declaration of rights". The latter provision requires a court to "declare that any law or conduct that is inconsistent with the Constitution, is invalid to the extent of its inconsistency"12 and permits it to grant "any order that is just and equitable."13 The central consideration for courts in crafting remedies for constitutional rights violations is to ensure the effective vindication and protection of the right violated. As the Constitutional Court has emphasised, this is important not only to the immediate victims of the relevant rights violations, but also to others similarly affected. ${ }^{14}$ In contrast to traditional private law remedies, the broader public interest is also a highly relevant factor in devising remedies to redress constitutional rights violations. The South African public has an interest in the effective protection of constitutional rights, which are fundamental to the fabric of our post-1994 constitutional democracy. ${ }^{15}$

Susan Sturm has argued for the need for a distinctive normative theory of public law remedies precisely because their effective vindication involves considerations, information and processes different from those involved in the merits or liability stage of litigation. The gap between right and remedy in constitutional litigation is frequently broad, because a determination that a right is infringed does not dictate the form of the remedy. This is particularly so when the rights violation stems from systemic institutional or organisational failures. Although commonly associated with socio-economic rights cases, such failures lie at the heart of all complex, polycentric constitutional rights cases. More often than not, there will be no one obvious remedial solution for remedying a constitutional violation of this nature, and

12 Section $172(1)(a)$.

13 Section 172(1)(b). This provision specifies that just and equitable remedies include an order limiting the retrospective effect of an invalidity order, and a suspended declaration of invalidity. For the broad range of just and equitable remedies available to the courts, see Bishop "Remedies" ch 9, 151 - 196; Liebenberg Socio-Economic Rights $397-450$.

14 Thus a court should in principle be prepared to grant any remedy for a constitutional rights violation that it awards to the individual party before it to all similarly affected parties: "[T] he litigants before the Court should not be singled out for the grant of relief, but relief should be afforded to all people who are in the same situation as the litigants." S v Bhulwana; S v Gwadiso 19961 SA 388 (CC), para 32.

15 In the words of Justice Ackermann in National Coalition for Gay and Lesbian Equality $v$ Minister of Home Affairs 20002 SA 1 (CC), the "bells toll for everyone" when constitutional rights such as equality and non-discrimination are infringed (at para 82). Also see Hoffman v South African Airways 20011 SA 1 (CC), paras 42 - 43. 
to "strike effectively at its source"16 will require processes of institutional reforms adopted over a period of time.

The structural remedies ${ }^{17}$ required to achieve such reforms depend on the participation of a broad range of organisations, institutions and stakeholders, some of whom may not have been represented at the merits stage of the litigation. ${ }^{18}$ As Sturm notes, "[t]he remedy may also affect the lives of individuals or groups who have no legal entitlement concerning the remedy but are in a position to block or disrupt its implementation."19 Incorporating a participatory dimension in constitutional remedies in this context thus make an important contribution to their effectiveness.

Sturm argues that the traditional binary, adversarial litigation process is not well suited to remedying structural constitutional rights violations. She accordingly develops an alternative model of participatory, deliberative public remedial decision-making. ${ }^{20}$ The latter classes of remedy resonate with the meaningful engagement remedy of the Constitutional Court, particularly in its judgment in the Olivia Road case. ${ }^{21}$ Moreover, many of the principles articulated by Sturm for evaluating public law remedies are consonant with South African constitutional remedial jurisprudence as well as with widely accepted principles of legitimate remedial decision-making.

Drawing on Sturm's analysis I proceed to identify four principles for evaluating the role that meaningful engagement has played in the remedial phase of the three educational rights judgments referred to above. These principles are:

1) fair participation;

2) substantive judicial reasoning;

$16 \quad$ Fose, para 96 (per Kriegler J).

17 On structural remedies, see Mbazira Litigating Socio-Economic Rights 165 - 225; Bishop "Remedies" ch 9, 175 - 196; Liebenberg Socio-Economic Rights 424 - 438.

Sturm 1991 The Georgetown LJ 1360-1365.

Sturm 1991 The Georgetown LJ 1364 - 1365.

20 See particularly Sturm 1991 The Georgetown LJ 1409 - 1446 where she makes the case for a distinctive deliberative model of remedial decision-making. For an analysis of the other models of structural remedies discussed by Sturm, see Mbazira Litigating Socio-Economic Rights 183 - 192.

21 Occupiers of 51 Olivia Road, Berea Township and 197 Main Street Johannesburg v City of Johannesburg 20083 SA 208 (CC). For analyses of the engagement remedy in Olivia Road, see Liebenberg 2012 AHRLJ 14 - 20; Chenwi "Democratizing the Socio-economic Rights-Enforcement Process" 185 - 188. 
3) a "demonstrable relationship"22 between the constitutional infringement found at the merits stage and the remedy imposed by the court; and

4) respect for the separation of powers doctrine.

\section{$2.1 \quad$ Full and fair participation}

The principle of full and fair participation aims to ensure that all parties to the litigation as well as those with a substantial interest in the outcome of the litigation ${ }^{23}$ have an opportunity to participate in the remedial process. In addition to the participation of the parties and those substantially affected by the rights violation, the principle of ensuring an effective remedy suggests that a court should structure the remedial process in such a manner as to enable the participation of individuals, groups and organisations that are able to facilitate or block the implementation of the remedy. ${ }^{24}$

Sturm describes the broader role of participation at the remedial stage of decision-making as being to promote cooperation amongst the different actors that must live by the plan. ${ }^{25}$ Related objectives of participatory processes include the "integrative function" [of] defining the community that is responsible for implementing the remedy, ${ }^{26}$ and the "educative function" of acquiring the information and developing the negotiation skills required to reform complex institutions and organisations. ${ }^{27}$

Ensuring that the participation process is fair requires measures to ensure that representatives of groups or organisations involved in the deliberations are representative of and accountable to the constituencies they represent. ${ }^{28}$ It also requires the establishment of mechanisms to mitigate as

22 Sturm 1991 The Georgetown LJ 1408.

23 Parties with a direct and substantial interest in the decision and remedy should be formally joined to the litigation. Thus, for example, local authorities are necessary parties to the eviction of occupiers from their homes given their broader constitutional and statutory obligations in terms of $s 26$ of the Constitution read with legislation such as the Prevention of Illegal Eviction from and Unlawful Occupation of Land Act 19 of 1998, the Housing Act 107 of 1997, and the Municipal Systems Act 32 of 2000. For a recent application, see Pheko v Ekurhuleni Metropolitan Municipality 20155 SA 600 (CC) paras 56 - 60. See Muller and Liebenberg 2013 SAJHR 554.

24 Sturm 1991 The Georgetown LJ 1410.

25 Sturm 1991 The Georgetown LJ 1391 - 1392.

26 Sturm 1991 The Georgetown LJ 1393.

27 Sturm 1991 The Georgetown LJ 1394.

28 Sturm 1991 The Georgetown LJ 1410. 
far as possible the unequal power relations arising from differential access to resources, information and skills. ${ }^{29}$ As Sturm observes:

The plaintiffs frequently are poor, politically powerless, and unorganized, and thus may be less able to influence the remedial decision. Yet, the values served by participation at the remedial stage depend on some direct involvement of those who must live with the results. An important criteria of remedial participation, therefore, is the capability of a particular form of remedial practice to control for unequal power, resources and sophistication. ${ }^{30}$

\subsection{Substantive reasoning in remedial decision-making}

Transparent, substantive judicial reasoning is not only critical to the legitimacy of judicial decision-making, but is also integral to the ethos of South Africa's transformative constitution. ${ }^{31}$ It gives effect in the context of adjudicatory decision-making to the "culture of justification,"32 which should pervade all exercises of power under our constitutional order, including judicial power. As Justice O'Regan observes:

A constitutional order requiring openness and accountability in relation to the exercise of public power cannot tolerate judicial avoidance of reasoning on fundamental constitutional values. ${ }^{33}$

The commitment to substantive reasoning should apply with equal force to both the merits and remedial phases of constitutional adjudication. In the remedial context, such reasoning would include, for example, elaborating on how the proposed remedy is related to the infringement of constitutional rights found at the merits stage, ${ }^{34}$ as well as a justification for the particular choice of remedy amongst the range of available remedial options.

It has been questioned whether participatory remedies (which attempt to stimulate agreement amongst the parties on the measures required to redress rights violations) are consistent with the principles of substantive judicial reasoning and the courts' interpretative responsibilities. Thus Owen Fiss has argued that reliance on party negotiation and agreement in the remedial process may tempt courts into abdicating their responsibilities "to explicate and give force to the values embodied in authoritative texts such as the Constitution and statutes: to interpret those values and to bring reality into accord with them." ${ }^{35}$ Whilst he acknowledges that parties cannot be

\footnotetext{
29 Sturm 1991 The Georgetown LJ 1410.

${ }^{30}$ Sturm 1991 The Georgetown LJ 1396 (footnotes omitted).

${ }^{31}$ Froneman 2005 Stell LR 3-20.

32 Mureinik 1994 SAJHR 32.

${ }^{33}$ O'Regan 2008 Acta Juridica 16.

${ }^{34}$ This aspect is elaborated upon in part 2.3 below.

35 Fiss 1984 Yale LJ 1085.
} 
forced to litigate, he draws attention to the public interest dimension of constitutional rights enforcement, which may be sacrificed when parties settle for peace instead of pursuing justice. ${ }^{36}$ Fiss reminds us that the effective redress of human rights has a broader public dimension beyond the interests of the immediate parties to the dispute.

Sturm contests the view that participatory remedial processes are incompatible with the responsibility of the judiciary for ensuring that constitutional rights and values receive reasoned explication and vindication in litigation. She points out that adversarial legal processes are not the only way of ensuring substantive reasoning in the remedial process of adjudication. ${ }^{37}$ This is particularly the case when the vindication of a constitutional norm can be achieved through a broad range of means, and the presiding judge is not as well placed as the parties and other stakeholders to determine how best to remedy the rights violation. ${ }^{38}$ In these contexts, Sturm argues that it is possible for a judge to enforce a fair deliberative process at the remedial stage of litigation whilst holding the parties accountable to substantively interpreted constitutional norms. ${ }^{39}$ In this regard, Sturm highlights the distinct judicial roles and objectives applicable at the merits and remedial stages of public litigation. In evaluating the engagement jurisprudence of the Constitutional Court in part 3 below, I consider how judicial responsibility for ensuring that the remedy gives effect to substantively reasoned constitutional norms may be preserved.

\subsection{A "demonstrable relationship" between right and remedy}

Closely related to the previous principle of reasoned remedial decisionmaking is a demonstrable relationship between the remedial order and the substantive right found to be infringed at the merits stage of constitutional adjudication. Failure to adhere to this principle renders judges vulnerable to accusations of abusing their coercive authority and failing to give parties and those affected a proper opportunity to be heard on the remedial solution imposed by the court. ${ }^{40}$

Again this is not an inevitable by-product of participatory remedial processes. It does caution, however, that such remedies should be structured so as to ensure that their relationship with the underlying

\footnotetext{
36 Fiss 1984 Yale LJ 1085.

37 Sturm 1991 The Georgetown LJ 1401.

38 Sturm 1991 The Georgetown LJ 1402.

39 Sturm 1991 The Georgetown LJ 1427 - 1444.

40 Sturm 1991 The Georgetown LJ 1408 - 1409.
} 
constitutional norms that have been found to have been breached can be demonstrated. In addition, it cautions courts to ensure that all parties affected by the constitutional breach have been given a proper opportunity to be heard in relation to the proposed remedy. Finally, a transparent, substantively reasoned connection between the rights found to be breached at the merits stage of the judgment and the remedial order provides the court with a set of normative criteria for evaluating the outcomes of the participatory remedial process.

\subsection{Respect for the separation of powers doctrine}

Respect for the separation of powers doctrine is a principle which applies not only in the exercise of a court's constitutional review powers, but also in the remedial phase of a case. ${ }^{41}$ In the remedial context, the doctrine requires that courts fulfil their responsibility under the South African Constitution for crafting effective remedies for infringements of constitutional rights. ${ }^{42}$ This responsibility arises from the principle of constitutional supremacy in section 2 of the Constitution, ${ }^{43}$ combined with the remedial obligations of the courts in terms of sections 38 and 172(1). ${ }^{44}$

However, in exercising these powers, separation of powers considerations caution courts to avoid usurping the legislative, executive or administrative functions of the coordinate branches of government. The legislature and executive enjoy greater democratic legitimacy as well as institutional capability in exercising these functions. Respect for the roles and functions of the legislature and executive as well as those of administrative bodies and organs of state constitutes the second significant separation of powers principle in a remedial context. ${ }^{45}$

41 On the role of the separation of powers in remedial decision-making in South African constitutional law, see: DPP, Transvaal v Minister for Justice and Constitutional Development 20094 SA 222 (CC) paras 183 - 184; National Coalition for Gay and Lesbian Equality v Minister of Home Affairs \& Others 20002 SA 1 (CC), paras 66, 74 - 76; Minister of Health v Treatment Action Campaign (No. 2) 20025 SA 721 (CC) paras $98-99$. On the application of the doctrine in the context of remedial decisionmaking in US public law, see Sturm 1991 The Georgetown LJ 1403 - 1406.

42 AllPay Consolidated Investment Holdings v CEO, SA Social Security Agency (No 2) 20144 SA 179 (CC) paras 42 - 46.

43 Section 2 of the Constitution reads: "The Constitution is the supreme law of the Republic; law or conduct inconsistent with it is invalid, and the obligations imposed by it must be fulfilled."

44 See ftns 12 and 13 above and the accompanying text.

45 For an account of the links between the doctrine of separation of powers and notions of judicial deference in South African public law, see Hoexter Administrative Law in South Africa 137-155. 
Reconciling the two principles of the separation of powers doctrine outlined above in the context of enforcing the positive duties imposed by rights in the Bill of Rights presents particular challenges for the judiciary. On the one hand, the courts must craft remedies that will provide effective relief for constitutional rights violations. On the other hand, they must avoid undue intrusions in the policy-making discretion of the relevant organs of state and afford them an appropriate latitude of policy choice and flexibility consistent with their mandate to govern effectively in the public interest. ${ }^{46}$

Meaningful engagement-style remedies offer a promising vehicle for reconciling these two principles. These remedies aim to stimulate participatory agreement on the precise policy measures required to remedy the rights violation identified by the courts at the merits stage. The court explicitly refrains from prescribing specific policy solutions to the parties, but instead requires them to work out, through deliberative engagement, a detailed plan of action to give effect to the court's merits findings. Organs of state are accorded a broad discretion to work out, in partnership with rights beneficiaries and stakeholders, the policy measures required to remedy the rights violation. Participatory, engagement-style remedies thus represent a departure from a traditional "command and control" style of judicial remedy ${ }^{47}$ Their primary objective is to stimulate the responsible organs of state to engage the rights beneficiaries, experts and other stakeholders to design an effective remedial plan of action.

However, the principle of ultimate judicial responsibility for ensuring an effective remedy implies that the court should retain supervisory jurisdiction so as to ensure that the agreed plan of action is consistent with the court's interpretation of the relevant rights at the merits stage. Without this

46 See, for example, the margin for policy adaptation allowed by the Court in respect of the mandatory orders it granted in Minister of Health $v$ Treatment Action Campaign (No. 2) 20025 SA 721 (CC) paras 114 and 127 read with Order No. 4, para 135. In City of Johannesburg Metropolitan Municipality v Hlophe [2015] 2 All SA 251 (SCA), the SCA overturned a broad-ranging reporting order against the City by Satchwell $J$ in the court a quo requiring a report on the steps the City was taking to secure alternative accommodation for all those facing homelessness as a result of the eviction of unlawful occupiers in Johannesburg. The SCA held that this aspect of the lower court's order transcended the issues in dispute and amounted to directing the City on how to comply with its obligations to provide temporary accommodation to homeless persons in general. According to the Court the form of the particular reporting order in the circumstances of the case infringed the principle of the separation of powers, and could not stand (paras $27-28$ ).

47 In this respect, it resembles the role of the courts envisaged in the democratic experimentalist legal literature. See Dorf and Sabel 1998 Columbia LR 267 - 473; Liebenberg and Young "Adjudicating Social and Economic Rights: Can Democratic Experimentalism Help?" $237-257$. 
supervisory element, participatory remedies run the risk of degenerating into privatised dispute-settlement. ${ }^{48}$ This would be contrary to the constitutional obligations of the courts to interpret and enforce fundamental rights.

The engagement process between the parties should be structured and guided by the substantive normative interpretation by the court of the relevant rights at the merits stage, and all elements of the remedial plan must be justifiable in terms of this interpretation. A well-structured remedial process should further generate a detailed record of the deliberations and how they relate to the merits judgment. This record can be of great assistance to the court in assessing the adequacy of the parties' agreed programme for remedying the rights violation. ${ }^{49}$

\subsection{Remedial principles: Summation}

The abovementioned principles provide a basis for evaluating participatory remedies, particularly in complex, polycentric cases involving a range of stakeholders. These kinds of cases call for a departure from the traditional model of binary (between two parties), adversarial, once-and-for-all remedies. The remedial principles discussed in this part seek to satisfy the demands of remedial efficacy as well as key features of legitimate judicial decision-making in constitutional democracies. ${ }^{50}$

In the following part, I analyse the role that meaningful engagement has played in three Constitutional Court education rights judgements, and evaluate this role in the light of the remedial principles discussed. All three cases unfolded against the backdrop of the complex, systemic problems besetting the education system in post-apartheid South Africa. As argued above, it is precisely this type of case which calls for innovative participatory remedies.

48 For an extended argument against a dispute settlement approach to constitutional rights infringements, see Fiss 1984 Yale LJ 1073 - 1090.

49 Sturm 1991 The Georgetown LJ 1435.

50 According to Sturm: "A legitimate model is one that takes each of these norms into account, strives to satisfy all of them, and strikes an appropriate balance amongst them given the demands and constraints of the particular remedial problem before the court" 1991 The Georgetown LJ 1410 - 1411. 


\section{Evaluating meaningful engagement in education rights cases}

\subsection{Determining a school's language policy: Hoërskool Ermelo}

\subsubsection{Analysis}

The case came before the Constitutional Court on appeal by the Head of the Mpumalanga (provincial) Department of Education ("HOD") against a judgment of the Supreme Court that it had acted unlawfully in revoking the function of the Hoërskool Ermelo public school to determine the language policy of the school and in conferring the function upon an interim committee appointed by him. The Supreme Court had set aside the intervention by the Head of Department as well as the decisions of the interim committee to amend the language policy of the school from Afrikaans single medium to English and Afrikaans parallel medium. ${ }^{51}$

Underlying the dispute concerning government's powers to intervene in school governance was the excess classroom and learner capacity of Hoërskool Ermelo. ${ }^{52}$ In comparison, schools in the school circuit of Ermelo catering primarily to African pupils had much higher learner-to-teacher ratios due to a shortage of classrooms and high enrolment numbers. ${ }^{53}$ As Moseneke DCJ noted in his judgment for a unanimous court, these realities illustrate the vast disparities in educational resources and the quality of education - a direct historical legacy of apartheid. ${ }^{54}$ Educational inequality has profound social consequences as it "entrenches historical inequity as it perpetuates socio-economic disadvantage. ${ }^{" 55}$

This situation came to a head when the Department sought to require the school in the 2007 new school year to admit grade 8 learners who could not be accommodated at any of the English medium schools in Ermelo because they were already full to capacity. ${ }^{56}$ The school adopted the stance that the

51 Hoërskool Ermelo v Head, Department of Education, Mpumalanga 20093 SA 422 (SCA).

52 The schools' learner-to-classroom ratio was 23:1 in comparison with the national average of 35:1. See Mpumalanga Department of Education v Hoërskool Ermelo 2010 2 SA 415 (CC) paras $7-10$ read with paras 15 and 20.

53 See Mpumalanga Department of Education v Hoërskool Ermelo 20102 SA 415 (CC) para 11.

54 Mpumalanga Department of Education v Hoërskool Ermelo 20102 SA 415 (CC) para 2.

55 Mpumalanga Department of Education v Hoërskool Ermelo 20102 SA 415 (CC) para 2.

56 For a detailed account of the development of the dispute, see Mpumalanga Department of Education v Hoërskool Ermelo 20102 SA 415 (CC) paras 12 - 20. 
learners would be eligible for admission only if they agreed to be taught in Afrikaans. An impasse developed, as the school refused to accede to the Department's demand to change its language policy to parallel medium in order to accommodate the 113 stranded learners unable to gain admission to a school. ${ }^{57}$ The HOD responded by purporting to withdraw with immediate effect the function of the school governing body to determine the school's language policy, and by appointing an interim committee for three months in order to perform the function of determining the school's language policy. The objective of the appointment of the interim committee was to change the language policy to include English as a medium of instruction so as to facilitate the admission of the learners who wished to be taught in English. ${ }^{58}$ In this regard, the HOD purported to act in terms of sections 22(1) and (3) and 25(1) of the South African Schools Act 84 of 1996 (hereafter the "Schools Act"). ${ }^{59}$ The Constitutional Court noted that it was common cause that this new language policy was adopted without consultation with relevant stakeholders such as the school governing body, the teaching staff, the learners already admitted to the school, or their parents..$^{60}$

The Constitutional Court held that the Supreme Court of Appeal had erred in finding that the HOD had no power under section 22(1) and (3) of the Schools Act to withdraw the power of the school governing body to determine a school's language policy. ${ }^{61}$ If "reasonable grounds" exist ${ }^{62}$ and the procedural fairness requirements of $s 22(3)$ are followed, ${ }^{63}$ the department's power to withdraw a function of a governing body extends also to the language policy of a school. The Court held that the conclusion was supported by a holistic construction of section 29 and the Schools Act, which requires that school language policies be designed so as to take into account the complex relationship between education in the language of one's choice, access to basic education by all children, the duty not to discriminate unfairly against any learners in admission to schools, and the

57 Mpumalanga Department of Education v Hoërskool Ermelo 20102 SA 415 (CC) paras $17-18$.

58 Mpumalanga Department of Education v Hoërskool Ermelo 20102 SA 415 (CC) paras $21-23,25-26$.

59 Mpumalanga Department of Education v Hoërskool Ermelo 20102 SA 415 (CC) para 21.

60 Mpumalanga Department of Education v Hoërskool Ermelo 20102 SA 415 (CC) para 27.

61 Mpumalanga Department of Education v Hoërskool Ermelo 20102 SA 415 (CC) paras $63-81$.

62 Section 22(1) of the Schools Act. The factors informing the assessment of reasonableness are set out by the Court in para 74 .

63 Mpumalanga Department of Education v Hoërskool Ermelo 20102 SA 415 (CC) para 75. 
imperatives of historical redress and transformation in the schooling system as a whole. ${ }^{64}$ Whilst governing bodies are intended to function as "beacons of grassroots democracy", ${ }^{65}$ the Court cautioned against a school's being governed "as a static and insular entity". A school is "a public resource which must be managed not only in the interests of those who happen to be learners and parents at the time but also in the interests of the broader community in which the school is located and in the light of the values of our constitution."66

However, the Court held that the HOD had acted unlawfully by invoking section 25 of the School's Act to appoint an interim committee to determine the school's language policy. ${ }^{67}$ This had also "contaminated" its recourse to section 22 of the Schools Act. ${ }^{68}$ Even if the appointment had been lawful, the Court held that the manner of its appointment and the way it proceeded to determine the new language policy did not satisfy the prescripts of procedural fairness. ${ }^{69}$

According to a traditional remedial approach, the finding of unlawfulness and the dismissal of the HOD's appeal ${ }^{70}$ should have been the end of the case. The situation of the individual Grade 8 learners who had been enrolled in the school since January 2007 in terms of the parallel medium policy had been resolved by an agreed order between the parties. This order (which

64 Mpumalanga Department of Education v Hoërskool Ermelo 20102 SA 415 (CC) paras $76-78$.

65 Mpumalanga Department of Education v Hoërskool Ermelo 20102 SA 415 (CC) 57 and 79 .

66 Mpumalanga Department of Education v Hoërskool Ermelo 20102 SA 415 (CC) para 80.

67 Section 25(1) of the Schools Act empowers the HoD to appoint persons to perform the functions of a governing body which he or she determines on reasonable grounds has ceased or failed to perform the functions allocated to it in terms of the School's Act. In casu, there were no grounds for concluding that the governing body of Hoërskool Ermelo had ceased to perform any function or failed to adopt a language policy. Mpumalanga Department of Education v Hoërskool Ermelo 20102 SA 415 (CC) para 86.

68 Mpumalanga Department of Education v Hoërskool Ermelo 20102 SA 415 (CC) para 89.

69 Mpumalanga Department of Education v Hoërskool Ermelo 20102 SA 415 (CC) para 92.

70 As noted above, the Constitutional Court overruled the SCA in respect of the power of an HOD to withdraw the function of a governing body to determine the language policy of a school in terms of $s$ 6(2) of the Schools Act provided that the requirements of $s$ 22 were satisfied. 
the Court affirmed) permitted the particular learners to continue to be taught and write exams in English until the end of their school careers. ${ }^{71}$

However, the Court held that the facts of the case called for the making of further just and equitable orders. The Court derived the power to make just and equitable orders from section 172(1)(b) of the Constitution, which it held did not depend on a finding of the constitutionality of legislation or conduct in terms of section 172(1)(a). ${ }^{72}$ Moseneke DCJ held as follows:

\begin{abstract}
This ample and flexible remedial jurisdiction in constitutional disputes permits a court to forge an order that would place substance above mere form by identifying the actual underlying dispute between the parties and by requiring the parties to take steps directed at resolving the dispute in a manner consistent with constitutional requirements. In several cases, this Court has found it fair to fashion orders to facilitate a substantive resolution of the underlying dispute between the parties. Sometimes orders of this class have taken the form of structural interdicts or supervisory orders. This approach is valuable and it advances constitutional justice particularly by ensuring that the parties themselves become part of the solution. ${ }^{73}$
\end{abstract}

The Court held that it was just and equitable "to all concerned" to direct the school governing body to reconsider and determine the school's language policy in the light of the considerations articulated in the judgment. The Court suggested that the school governing body would need to give serious consideration to adapting its language policy to cater for these learners, given its dwindling enrolment numbers and the need to redress the unequal access to education perpetuated by the current Afrikaans-only language policy. ${ }^{74}$

It noted that the underlying problem in the Ermelo school district was the shortage of classroom places for learners who choose English as their language of instruction. This situation was clearly a structural one relating to the legacy of disadvantage affecting mainly schools in the former black group areas. Without concerted action, the problem of the shortage of classroom places for black learners choosing to be educated in English in future was likely to persist, and securing additional places at Hoërskool Ermelo would afford only a partial alleviation of this problem. The Department of Education bore constitutional and statutory duties to provide

71 Mpumalanga Department of Education v Hoërskool Ermelo 20102 SA 415 (CC) para 95.

72 Mpumalanga Department of Education v Hoërskool Ermelo 20102 SA 415 (CC) para 97.

73 Mpumalanga Department of Education v Hoërskool Ermelo 20102 SA 415 (CC) para 97 (footnotes omitted).

74 Mpumalanga Department of Education v Hoërskool Ermelo 20102 SA 415 (CC) para 100. 
basic education in an official language of choice to everyone, where it was reasonably practical and just to do so. The Court was not satisfied that the Department had taken the necessary "proactive and timely steps" 75 to secure sufficient Grade 8 English school places and to alleviate the high level of overcrowding in the Ermelo district high schools.

In the light of these considerations, after dismissing the appeal, the Court made further ancillary orders. The first order required the Hoërskool Ermelo School Governing Body to review and determine a language policy in terms of section 6(2) of the Schools Act and the Constitution, and to report back to the Court within 3 months on the process that had been followed to review its language policy, and attaching a copy of the language policy. Secondly, the Head of the Mpumalanga Department of Education was also ordered to lodge a report with the court within 3 months "setting out the likely demand for grade 8 English places at the start of the school year in 2010 and setting out the steps the Department has taken to satisfy this likely demand for an English or parallel medium high school in the circuit of Ermelo."76

\subsubsection{Evaluation}

Although not expressly invoking the concept of meaningful engagement, the spirit of the judgment and supervisory orders envisages participatory processes. This is implicit in the requirement that in revising its language policy in accordance with the Constitution and relevant legislation, the school governing body should take into account not only the existing school community but also the broader needs of the community in which the school was located. Furthermore, the provincial education department would have to embark on an information-gathering and broad consultative process in order to comply with the supervisory order requiring it to plan and report on the steps it was taking to satisfy the likely demand for grade 8 English places in the new school year.

These ancillary supervisory orders were made by the court in recognition of the underlying structural problems of educational access and quality in the Ermelo school district. An effective, sustainable solution to these structural problems required a broad-based participatory process for the reasons

75 Mpumalanga Department of Education v Hoërskool Ermelo 20102 SA 415 (CC) para 103.

76 Mpumalanga Department of Education v Hoërskool Ermelo 20102 SA 415 (CC) para 106. In its judgment the Court held that the report provided by the Department "must also provide information and statistics on the levels of enrolment in other high schools in the area in the light of the learner-to-class ration norms set by the Minister of Education." (para 104). 
given by Sturm: garnering the requisite information from stakeholders; resolving differences through fair deliberative processes; and fostering broad "buy-in" to the proposed policy and programmatic solutions. ${ }^{77}$

However, the judgment and relevant supervisory orders could have been more explicit regarding the requirement that the governing body and department engage meaningfully both with each other and other stakeholders with a substantial interest in educational rights in the Ermelo district. This would have clarified that the policy and planning processes envisaged in the orders should occur through a participatory process involving all individuals, organisations and institutions whose input was necessary to ensuring that the objectives of the supervisory orders were met. As Sturm observes, the deliberative public law remedial model requires an assessment "of the individuals and organizations whose participation in the remedial stage is necessary to developing and implementing a fair and workable remedy." 78 This may include the recruitment of parties at the remedial stage who were not involved at the liability stage. ${ }^{79}$ In terms of the deliberative remedial model, the parties are also invited to consider how the participatory process could be structured so as to ensure fair participation by all relevant stakeholders. A more explicit incorporation of meaningful engagement in the remedial orders handed down in the Hoërskool Ermelo case would have given effect to the first remedial principle of fair participation discussed above. ${ }^{80}$

The second criticism that could be levelled against the remedial orders in Hoërskool Ermelo is the lack of a demonstrable relationship between the findings at the merits stage of the judgment and the remedial orders. This implicates the third remedial principle discussed above. ${ }^{81}$ As noted above, the narrow issue before the Court was the legality of the HOD's intervention, which was found to be in contravention of relevant provisions of the Schools Act. The HOD's appeal was accordingly dismissed (albeit on grounds different from those in the SCA's judgment). The decision by the Court to

77 See the quotation in the text accompanying ftn 73 above.

78 Sturm 1991 The Georgetown LJ 1429.

79 Sturm identifies four possible procedural mechanisms for enabling the participation of actors who were not involved in the liability phase of the litigation (at 1429, ftn 395). All these mechanisms would in principle be capable of being applied or developed in terms of a constitutionally-directed development of the South African rules of civil procedure. In the context of the Hoërskool Ermelo case, relevant stakeholders that could have been invited to participate in the remedial process are other school governing bodies in the Ermelo district, parent organisations, NGOs focusing on educational rights, and the South African Human Rights Commission.

80 See part 2.1 above.

81 See part 2.3 above. 
make the further ancillary orders referred to above was based on the need both to resolve the underlying disputes between the parties by requiring the adoption of a constitutionally compliant language policy by the school, and for the Department to take proactive steps to secure sufficient English school places. As discussed above, the underlying purpose of ensuring a demonstrable relationship between constitutional breach and remedy is to safeguard the legitimacy of judicial orders, ensure fairness to the parties, and provide a transparent normative standard against which to test the outcomes of a participatory remedial process. Arguably the underlying disputes which informed the ancillary orders were sufficiently closely connected to the legality dispute and had been adequately canvassed in the legal proceedings in three courts. The Court elaborated in some detail in its judgment the principles which governing bodies should take into account in formulating a language policy which is consistent with the provisions of section 29(2) of the Constitution. ${ }^{82}$ Arguably there was therefore sufficient normative guidance provided in the judgment both to the Hoërskool Ermelo Governing Body and to other governing bodies in South Africa on the formulation of constitutionally compliant school language policies.

However, similar elaboration was not provided in the main judgment on the nature of the positive duties of the Department of Education to take "proactive and timely" steps to ensure sufficient school places for learners choosing English as their language of instruction. Such measures would entail a complex interaction and reconciliation of the duties imposed by sections 29(1)(a) and (2) respectively. ${ }^{83}$ The Department would need to engage in a procedurally fair manner with Afrikaans single-medium schools with excess capacity in an attempt to persuade them to adapt their language policy to accommodate learners who chose instruction in English. At the same time, it would have to procure additional resources so as to construct

82 Mpumalanga Department of Education v Hoërskool Ermelo 20102 SA 415 (CC) paras $45-54$; paras $75-81 ; 99-100$.

83 In Governing Body of the Juma Musjid Primary School v Essay NO 20118 BCLR 761 (CC), the Constitutional Court implied that the concept of "basic education" in section 29(1)(a) corresponds with the period of compulsory schooling prescribed in section $3(1)$ of the Schools Act (para 38). Compulsory school attendance in terms of the latter provision extends to learners from the age of seven years until the age of 15 years or until the learner reaches the ninth grade, whichever occurs first. On this interpretation, the duty to secure sufficient placement for grade 8 learners would fall within the scope of the unqualified right to basic education in s 29(1)(a). In terms of section 3(3) of the Act, the MEC is required to ensure that there are enough school places so that every child who lives in his or her province can attend school as required by section 3(1). Also see Minister of Basic Education v Basic Education for All [2015] ZASCA 198 paras $35-38$. Academic literature supports a broad, functional interpretation of the right to basic education, see Simbo 2012 LDD 162 - 184; McConnachie and McConnachie 2012 SALJ 565 - 568; Murungi 2015 PER 3160 - 3195. 
and establish one or more new English or parallel medium high schools. Scant guidance was provided in the judgment on the constitutional normative principles which would have to guide the Department in fulfilling its responsibilities in term of section $29 .{ }^{84}$ Given that these issues are also of significant public importance to both public educational authorities and all involved in education in South Africa, one would have expected greater elaboration on the obligations of the Department in terms of section 29(1) read with (2) of the Constitution.

The third point of criticism is that no further judgment was delivered by the Constitutional Court after issuing its supervisory orders. It is therefore unclear if the Court was satisfied that the content of the reports filed reflected adequate compliance with the constitutional principles outlined in its judgment. The supervisory orders issued by the Court demonstrate respect for the separation of powers doctrine by requiring the relevant organs of state to work out the details of the relevant educational policy and plans to give effect to the constitutional principles articulated in the judgment. ${ }^{85}$ However, the absence of any follow-up judgment assessing whether or not the reports of the parties evinced a satisfactory compliance with the initial judgment raises the question whether the Court fulfilled its own constitutional responsibility to ensure effective relief for the underlying constitutional issues identified in its judgment. ${ }^{86}$ This also implicates the fourth remedial principle concerning the separation of powers.

Moreover, a judgment by the court pertaining to the outcome of the supervisory orders issued by it would have given effect to the third principle concerning substantive judicial reasoning at the remedial stage of adjudication. ${ }^{87}$ Such a judgment could have provided guidance to all organs of state and stakeholders involved in the implementation of constitutional

84 See, for example, the broad observations made at paras $100-104$.

85 See the fourth remedial principle discussed in part 2.4 above.

86 The Constitutional Court has on a number of occasions delivered subsequent judgments dealing with various aspects of supervisory orders made in its initial judgment. See, for example: Residents of Joe Slovo Community, Western Cape $v$ Thubelisha Homes 20117 BCLR 723 (CC) (discharging the eviction order in response to a failure by the respondents to implement the supervisory orders made in the initial judgment); Pheko v Ekhurhuleni Metropolitan Municipality 20155 SA 600 (CC) (determining whether the municipality should be held in contempt for failure to comply with the Court's reporting orders and joining further parties to the proceedings for the purposes of implementing the relevant supervisory orders); AllPay Consolidated Investment Holdings (Pty) Ltd v Chief Executive Officer of the South African Social Security Agency 20156 BCLR 653 (CC) (determining an application by one of the parties for ancillary relief to the supervisory orders made by the Court in the remedies judgment).

87 See the third remedial principle discussed in part 2.3. 
educational rights in South Africa, thereby vindicating the broader public interest in the remedy issued in the Hoërskool Ermelo case.

In conclusion, the supervisory orders issued in Hoërskool Ermelo represent a modest but nonetheless significant attempt to stimulate the parties to seek a solution to the underlying constitutional issues identified in the judgment. However, the reasons for making these orders could have been more substantive, and they could have been structured to give better effect to the four constitutional remedial principles discussed in part 2. The fact that the case was presented to the courts primarily as a dispute concerning the legality of the MEC's intervention in the language policy of the school meant that the case did not lend itself to a sustained focus on the structuring of the participatory aspects of the supervisory orders. It is commendable, nevertheless, that the Constitutional Court engaged with the underlying structural causes of the dispute and their implications for section 29 rights.

The nascent potential of participatory engagement remedies in the context of structural educational rights disputes is evident in the Hoërskool Ermelo judgment. This remedy was developed further in another major Constitutional Court case concerning the impact of school governance policies on constitutional rights, the Welkom High School case.

\subsection{School pregnancy policies: The Welkom High School}

\subsubsection{Analysis}

Meaningful engagement featured prominently in an education rights context in the Welkom High School case. ${ }^{88}$ As with the Hoërskool Ermelo case, the legal dispute in Welkom High School was framed as a power struggle regarding who had the ultimate say over the formulation and implementation of school policies, specifically learner pregnancy policies in terms of which

88 Meaningful engagement previously featured as an element of the provisional orders made by the Constitutional Court in the case of Governing Body of the Juma Musjid Primary School v Essay NO 20118 BCLR 761 (CC) (see paras 74 - 78). These orders were made in an attempt to achieve the resolution of a dispute concerning the closure of a public school operating on land owned by a private trust. When the resolution failed, the Department was further ordered to engage with the parents of the affected learners to secure alternative school placements for them. The Court's judgment focused on the relevant constitutional obligations of the Trust and of the Department of Education in the circumstances. Ultimately, the Court ordered the school to vacate the Trust's premises on the basis that it was satisfied that suitable alternative educational placements had been found for the affected learners. As the judgment did not focus on the reasons for meaningful engagement in its provisional orders, it is not analysed in further detail. However, it constitutes another illustration of the potential of meaningful engagement in implementing court orders in the context of fundamental rights litigation. 
two schools had excluded two pregnant learners from school for protracted periods. The impact of the relevant policies would have been to force the learners to repeat a school year. ${ }^{89}$ The Head of the provincial Department of Education (the HOD) had instructed the principals of the schools to readmit the two learners. In response, the relevant school governing bodies had sought and obtained interdictory relief in the High Court against the HOD, restraining interference in decisions taken by the schools in terms of their learner pregnancy policies. These orders were confirmed in essence on appeal by the HOD to the Supreme Court of Appeal.

A further appeal by the HOD against the restraining order to the Constitutional Court was dismissed. Khampepe $\mathrm{J}$ (author of the main judgment for the majority) noted that the Act envisages a "partnership" involving the State, parents of learners and members of the community in which the school is located. The Schools Act closely regulates the roles and interactions between the parties, creating "the checks, balances and accountability mechanisms." 90 The governing body of a school is responsible for adopting the necessary policies and programmes to guide the management of the school and to create an environment for the realisation of the right to education in the school. This includes the power to adopt a policy regulating learner pregnancies. ${ }^{91}$ No school governing body was permitted to adopt policies and exercise powers that were contrary to the fundamental rights of pregnant learners to be free from unfair discrimination. ${ }^{92}$ However, the School's Act did not empower the HOD to by-pass the school governing bodies and issue direct instructions to the principals of the schools contrary to the terms of the relevant policies. ${ }^{93}$ Section 22 of the Schools Act determines the circumstances and manner in which a HOD could intervene directly and take over the performance of the particular governance or policy-formulation function of a school.

89 Head of Department, Department of Education, Free State Province $v$ Welkom High School 20142 SA 228 (CC) paras 8 - 21.

90 Head of Department, Department of Education, Free State Province $v$ Welkom High School 20142 SA 228 (CC) para 49.

91 Head of Department, Department of Education, Free State Province v Welkom High School 20142 SA 228 (CC) paras $57-70$. On the specific stipulations that such a pregnancy policy could include, see para 64.

92 Head of Department, Department of Education, Free State Province v Welkom High School 20142 SA 228 (CC) para 71. Pregnancy, sex and gender are explicitly recognised as prohibited grounds of unfair discrimination in terms of $s 9$ of the Constitution read with $s 1$ of the Promotion of Equality and Prevention of Unfair Discrimination Act 4 of 2000 , the legislation enacted to give effect to this constitutional right.

93 Head of Department, Department of Education, Free State Province $v$ Welkom High School 20142 SA 228 (CC) paras $72-82$. 
Consultation with the relevant governing body on the basis of a reasonable belief that the HOD should take over the governing bodies' functions of formulating pregnancy policies was a jurisdictional pre-requisite to the exercise of this power in terms of section 22 of the Act. ${ }^{94}$ Alternatively, the HOD's remedy was to approach a court in order to have the allegedly unconstitutional policies set aside. ${ }^{95}$ The failure by the HOD to follow these procedures was contrary to the principle of legality even when he purportedly acted in terms of section 7(2) if the Constitution to protect the fundamental rights of pregnant learners. ${ }^{96}$ The State's duty to protect rights in terms of section 7(2) of the Constitution did not allow available internal legal remedies to be ignored, nor did it countenance a resort to self-help. ${ }^{97}$ This approach also accorded with the separation of powers doctrine, which requires the Executive to respect the remedies enacted by Parliament through "the sensitive scheme of powers" of the Schools Act. ${ }^{98}$ The majority of the Court therefore concluded that the schools were entitled to the interdictory relief granted in the lower courts.

However, relying on reasoning similar to that in the Hoërskool Ermelo case, the Court held that even though the constitutionality of the relevant pregnancy policies was not before the Court, it would be remiss of it not to deal with the serious concerns regarding the constitutionality of the relevant policies. The legal basis for addressing the underlying constitutional concerns was the broad, equitable remedial discretion vested in the Court by section 172(1)(b) of the Constitution. The discretion to grant relief "on the basis of claims that were not raised (directly, fully or at all) by the parties" was not unlimited and had to be "exercised with caution and in a judicial manner, to ensure that justice is served." 99

In the present case, the Court held that it was ill-placed to make a conclusive determination regarding the substantive content of the policies, given that the respondent schools had declined to make submissions on the

94 Section 22 of the Schools Act (cited at ftn 41 of the Welkom High School judgment.) Section 22(3) provides for ex post facto representations in cases of urgency.

95 Head of Department, Department of Education, Free State Province v Welkom High School 20142 SA 228 (CC) para 90, 97.

96 Head of Department, Department of Education, Free State Province $v$ Welkom High School 20142 SA 228 (CC), para 105.

97 Head of Department, Department of Education, Free State Province $v$ Welkom High School 20142 SA 228 (CC) para 86.

98 Head of Department, Department of Education, Free State Province v Welkom High School 20142 SA 228 (CC) para 87.

99 Head of Department, Department of Education, Free State Province $v$ Welkom High School 20142 SA 228 (CC) paras 107 - 109. 
constitutionality of the policies. ${ }^{100}$ Their position was that the constitutionality of these policies was not properly before the Constitutional Court. Nevertheless, relying on section 172(1)(b), the Court proceeded to analyse the relevant policies and their impact on the constitutional rights of pregnant learners. It concluded that the policies "prima facie" violate a number of constitutional rights. ${ }^{101}$ These rights are the rights against unfair discrimination on the grounds of pregnancy and sex in terms of section 9(3); the right to basic education in terms of section 29; the rights to human dignity, privacy and bodily and psychological integrity in terms of sections 10,14 and 12(2) respectively; and the principle enshrined in section 28(2) that a child's best interests are of paramount importance in every matter concerning the child. ${ }^{102}$

A key consideration in making further ancillary remedial orders in the case was that it was necessary to provide clarity on what the Constitution and Schools Act allow or do not allow in relation to the content of school pregnancy policies. These policies have a profound effect on the rights of children who were not party to these proceedings, and who may never independently challenge similar policies. ${ }^{103}$ Given this confusion on the constitutionality of the schools' pregnancy policies, the Court held that it would be necessary for the governing bodies and the Free State HOD "to engage meaningfully in order to provide clarity on this issue." 104 The engagement order which the Court ultimately gave was also justified by reference to the principles of co-operative government enshrined in chapter 3 of the Constitution and the overall scheme of the Schools Act. ${ }^{105}$

In the light of the fact that the schools had not made submissions justifying the constitutionality of the policies, the Court refrained from declaring the policies invalid. ${ }^{106}$ After dismissing the appeal, it ordered the school governing bodies to review their pregnancy policies in the light of the

100 Head of Department, Department of Education, Free State Province $v$ Welkom High School 20142 SA 228 (CC) para 110.

101 Head of Department, Department of Education, Free State Province $v$ Welkom High School 20142 SA 228 (CC) para 112.

102 Head of Department, Department of Education, Free State Province $v$ Welkom High School 20142 SA 228 (CC) paras 113 - 116.

103 Head of Department, Department of Education, Free State Province $v$ Welkom High School 20142 SA 228 (CC) para 119.

104 Head of Department, Department of Education, Free State Province $v$ Welkom High School 20142 SA 228 (CC) para 119.

105 Head of Department, Department of Education, Free State Province v Welkom High School 20142 SA 228 (CC) paras $120-126$.

106 Head of Department, Department of Education, Free State Province $v$ Welkom High School 20142 SA 228 (CC) para 125. 
judgment, to report back to the Court on the processes followed, and to furnish copies of the revised policies. ${ }^{107}$ Crucially, the Court ordered the schools and the Department of Education to "engage meaningfully" with each other in order to give effect to the orders requiring the revision of the policies. ${ }^{108}$

In their separate concurring judgment, Froneman and Skwyeyiya JJ elaborated on the importance of co-operative governance and meaningful engagement in resolving disputes between the various bodies involved in the education system. They held that that there was a constitutional obligation on the partners in education to engage in good faith with each other on matters of education before turning to the courts. ${ }^{109}$ The Justices held that the emphasis on participation and engagement finds particular recognition in the constitutional requirements of co-operative government. ${ }^{110} \mathrm{~A}$ detailed analysis was conducted in the concurring judgment of how the parties had failed to live up to the demands of cooperative engagement and to ensure the best interests of the learners in their interactions leading up to the litigation. ${ }^{111}$ The concurring judgment emphasised timely, structured and sustained engagement between the parties as "as the most powerful barrier against these types of disputes arising and the learners' interests being compromised in the process."112 The duty to engage, co-operate and communicate in good faith persisted even in a crisis requiring immediate redress. The concurring judgment supported the remedial order of the main judgment, underscoring the

107 Head of Department, Department of Education, Free State Province $v$ Welkom High School 20142 SA 228 (CC) para 128 (order 3).

108 Head of Department, Department of Education, Free State Province v Welkom High School 20142 SA 228 (CC) para 128 (order 4).

109 Head of Department, Department of Education, Free State Province v Welkom High School 20142 SA 228 (CC) para 135.

110 Constitution, s 40. The principles of co-operative government and intergovernmental relations recognised by the Constitution include the duty of all spheres of government and all organs of state to "co-operate with one another in mutual trust and good faith by -

(i) fostering friendly relations;

(ii) assisting and supporting one another;

(iii) informing one another of, and consulting one another on, matters of common interest;

(iv)co-ordinating their actions and legislation with one another;

(v) adhering to agreed procedures; and

(vi) avoiding legal proceedings against one another." (s 41(1)(h))

The Court confirmed that these duties were binding on school governing bodies and HODs, who were organs of State (para 141).

111 Head of Department, Department of Education, Free State Province v Welkom High School 20142 SA 228 (CC) paras $154-166$.

112 Head of Department, Department of Education, Free State Province $v$ Welkom High School 20142 SA 228 (CC) para 166. 
importance of the school governing body and the provincial Department of Education adhering to the tenets of engagement described in the judgments in the process of reviewing the relevant pregnancy policies. In reporting back to the Court on progress made, it was emphasised that "the learners' best interests should lie at the heart of any solutions reached."113

A dissenting judgment by Zondo $\mathrm{J}$ (in which three other justices concurred) rejected the proposition that the case should be decided on the basis of the principles of co-operative governance and engagement, as this point had not been raised by either party. Deciding the case on this basis would deprive the HOD of an opportunity to be heard on a central issue in deciding the case contrary to the principles of audi alteram partem. ${ }^{114}$ The minority judgment would have upheld the appeal of the HOD on the basis that he had both a legal obligation and the power to take active steps to protect the constitutional rights of pregnant learners, and to prevent the implementation of policies that were manifestly inconsistent with the Constitution, the Schools Act, and the Promotion of Equality and Prevention of Unfair Discrimination Act.

\subsubsection{Evaluation}

The first criticism that can be levelled against the engagement order in Welkom High School is that it fails to give full effect to the first remedial principle regarding full and fair participation in the engagement process. ${ }^{115}$ The order makes provision only for the HOD and the respondent schools to engage with one another. However, effective and meaningful engagement on school pregnancy policies requires the inputs of a broader range of stakeholders with experience and expertise in this area. These stakeholders include representatives of the directly affected rights-holders themselves pregnant learners, ${ }^{116}$ the Commission for Gender Equality, the Human Rights Commission, representative organisations of school governing bodies, as well NGOs and academics specialising in gender equality, children's rights and the right to education. This broader stakeholder

113 Head of Department, Department of Education, Free State Province $v$ Welkom High School 20142 SA 228 (CC) para 167.

114 Head of Department, Department of Education, Free State Province $v$ Welkom High School 20142 SA 228 (CC) para 264.

115 See part 2.1 above.

116 On the significance of hearing the voice of children in decisions affecting them, see Christian Education South Africa v Minister of Education 20004 SA 757 (CC) para 53 (per Sachs J); For an analysis of the principles and mechanisms for promoting child participation in social dialogue, see Nolan Children's Socio-Economic Rights, Democracy and the Courts 71-83; Jamieson et al (eds) South African Child Gauge $18-73$. 
involvement would have contributed to more expert, broadly acceptable school pregnancy policies and would have facilitated the integrative and educative functions of engagement processes identified by Sturm. ${ }^{117}$

In addition, through recruiting a broader range of parties to the engagement order, the Court could have helped ensure that the outcomes of the engagement order had a broader systemic impact on school pregnancy policies in South Africa, rather than being framed primarily in terms of facilitating a resolution of the dispute between the immediate parties to the litigation. ${ }^{118}$ This broader public dimension of the case is manifest in the main judgment's acknowledgment that the question of the constitutionality of school pregnancy policies had far-reaching effects on children who were not party to the proceedings. ${ }^{119} \mathrm{~A}$ more structured engagement process could also have provided more guidance on the basic principles that should inform the process of engagement to make it fair. For example, Froneman and Sweyiya JJ give some indications of how the duty of good faith was not adhered to in the interactions of the parties, ${ }^{120}$ but this aspect is not developed in relation to the implementation of the engagement order.

The main and concurring judgments in Welkom High School provide a relatively expansive justification for the role of cooperation and engagement in seeking to resolve school governance disputes. Thus Khampepe $J$ reasoned that cooperation and engagement are central to the partnership model of school governance, which is in turn a critical factor in the delivery of quality education. In addition to serving as a mechanism for avoiding public confrontation and litigation, engagement provides a structured process for remedying policies that raise serious constitutional concerns. ${ }^{121}$ The concurring judgments of Froneman and Skweyiya JJ drew an even more explicit link between "good faith engagement" and institutional processes designed to give effect to constitutional rights. ${ }^{122}$ Patient, persistent, good faith engagement was cast in the concurring judgment not only as a matter of good school governance but as being essential to

117 See the text accompanying ftn $26-27$ above.

118 The broader systemic role of participatory remedies is significant to avoiding the narrow dispute-resolution role of party settlement negotiations criticised by Fiss. See the text accompanying ftn $35-36$ above.

119 Head of Department, Department of Education, Free State Province v Welkom High School 20142 SA 228 (CC) para 119.

120 Head of Department, Department of Education, Free State Province $v$ Welkom High School 20142 SA 228 (CC) para 164.

121 Head of Department, Department of Education, Free State Province v Welkom High School 20142 SA 228 (CC) para 125.

122 Head of Department, Department of Education, Free State Province $v$ Welkom High School 20142 SA 228 (CC) para 139. 
ensuring that the learners' best interests were protected. ${ }^{123}$ In this respect the Welkom High School judgment fares better than the Hoërskool Ermelo judgment in giving effect to the second remedial principle concerning substantively reasoned remedial decision-making. ${ }^{124}$ It explains in some detail why meaningful engagement is a critical vehicle for fulfilling education rights and remedying violations of these rights. However, as argued previously, this substantively reasoned justification for engagement in education rights disputes does not extend the actual structuring of the engagement process to ensure inclusive and fair participation.

Another area in which the Welkom High School judgment is vulnerable to criticism is that it lacks a demonstrable relationship between the constitutional violation found at the merits stage and the specific remedial orders issued. ${ }^{125}$ The Court relied on the Hoërskool Ermelo precedent to depart from the narrow issues raised by the legality challenge on the basis that it was necessary to deal with the substantive dispute between the parties. In contrast to the Hoërskool Ermelo case, where the Court arguably did not have sufficient arguments and information before it to deal thoroughly with the complex issue of language and educational access, the constitutionality of the relevant pregnancy policies in Welkom High School was more straight-forward. The text of the relevant pregnancy policies and the manner of their application to individual pregnant learners were before the Court. Although school governing bodies did not have a full hearing on the justifiability of the policies (given their view that these policies were not properly before the court), a plausible justification for these manifestly discriminatory policies is hard to imagine. As noted above, the Court did not declare the policies unconstitutional, instead making the rather unusual finding that the relevant policies were prima facie in violation of a range of constitutional rights. ${ }^{126}$ On the basis of this finding, the school governing bodies were ordered to revise the policies taking into account the interpretation of constitutional rights and guidance provided in the judgment and through a process of engagement with the Department of Education. It is arguable in the circumstances that a sufficient link was established between the remedial orders made and the constitutional defects identified in the merits judgment.

\footnotetext{
123 Head of Department, Department of Education, Free State Province $v$ Welkom High School 20142 SA 228 (CC) paras 145 - 147; $164-166$.

124 See part 2.2 above.

125 See part 2.3 above.

126 See footnotes $101-102$ above, and the accompanying text.
} 
The engagement order in Welkom High School gave effect to the doctrine of the separation of powers ${ }^{127}$ by preserving a realm of policy choice by the school governing bodies in designing new constitutionally-compliant pregnancy policies. However, as was the case in Hoërskool Ermelo, the Court issued no follow-up judgment consequent upon its supervisory orders, requiring the governing bodies to report back to the court both on the process followed in revising their pregnancy policies and to furnish copies of the relevant policies. No public judgment accordingly exists on whether the parties complied with the procedural obligations imposed upon them to engage meaningfully with each other in revising the pregnancy policies nor on whether the revised policies comply with the substantive guidelines in the main judgment on the implications of the various constitutional rights at stake.

This is problematic in terms of providing broader guidance for the benefit of similarly affected learners on the implications of the Constitution and the Schools Act for school pregnancy policies. ${ }^{128}$ The lack of a follow-up judgment in response to supervisory remedies implicates the third and fourth remedial principles discussed above: substantive, transparent judicial reasoning and the principle of the separation of powers. Whilst the latter principle requires respect for the policy-making discretion of organs state, it also requires that a court ensure an effective remedy for constitutional rights violations. A subsequent public judgment would have vindicated the broader public interest in the constitutional dispute, and helped ensure constitutionally compliant pregnancy policies throughout the public schooling system in South Africa. The failure to deliver such a follow-up judgment was also a lost opportunity for the Court to provide guidance on the processes of meaningful engagement, particularly given the sharp difference of opinion between the majority and the minority on whether there had been sufficient engagement in the circumstances of the case. ${ }^{129}$

In conclusion, the Welkom High School case demonstrates the potential of participatory remedies to redress violations of constitution rights in environments where sustained co-operation and engagement amongst a wider range of stakeholders is required to secure a sustainable, effective

127 See the fourth remedial principle discussed in part 2.4 above.

128 This was a rationale which the Court itself gave for engaging with the constitutionality of the substance of the pregnancy policies in its remedial orders. See footnote 103 above and accompanying text.

129 Compare the detailed guidance provided in Occupiers of 51 Olivia Road, Berea Township and 197 Main Street Johannesburg v City of Johannesburg 20083 SA 208 (CC) paras 14 - 22 on the requirements of meaningful engagement. 
remedy. However, the full potential of the engagement remedy in the Welkom High School case was not realised due to the shortcomings discussed above.

\subsection{School admission policies: Rivonia Primary School}

\subsubsection{Analysis}

The third case in the trilogy discussed in this article, Rivonia Primary School, also came before the Constitutional Court in the form of a challenge to the lawfulness of interventions by the Department of Education to overturn decisions of the school governing body and the principal of a public school. The underlying dispute concerned who had the final say over learner admissions to a public school.

The school governing body of Rivonia Primary School had determined the capacity of Grade 1 enrolment in the school to be 120 learners, and refused admission to a Grade 1 learner on the basis that the school was full. The learner was accordingly placed on a waiting list for admission. The mother of the learner approached the HOD of education in the Gauteng province for assistance. The HOD was of the view that the school did have the capacity to admit the additional learner. Purporting to exercise his powers in terms of provincial regulations, he proceeded to overturn the refusal of the learner's application and issued an instruction to the school to admit the learner with immediate effect. When the principal refused to admit the learner, the HOD withdrew her admissions function and delegated it to another official, who proceeded to admit the learner to the school. The principal was subsequently subject to a disciplinary hearing for failing to comply with the HOD's instruction. ${ }^{130}$

The school approached the South Gauteng High Court on an urgent basis for declaratory relief and an interdict to invalidate the Department's decision to override the school's admission policy, the forced admission of the learner, and the withdrawal of the principal's admission function. This relief was rejected by the High Court on the basis that the Department is empowered to intervene where necessary to protect children's access to schooling. ${ }^{131}$ The school governing body's appeal to the Supreme Court of Appeal was upheld on the basis that the school governing body was vested

130 MEC for Education v Governing Body of the Rivonia Primary School 20136 SA 582 (CC) paras $9-15$.

131 MEC for Education v Governing Body of the Rivonia Primary School 20136 SA 582 (CC) paras 16 - 20. 
with the power to determine the admission policy and capacity of the school. ${ }^{132}$

The MEC for Education appealed this judgment to the Constitutional Court. A majority of the Constitutional Court (per Mhlantla AJ as she then was) held that, although a School Governing Body did have the power to determine the school's capacity, the provincial education department retained ultimate authority over admissions in terms of both the Schools Act and provincial education regulations. ${ }^{133}$ In this regard, the Constitutional Court overruled the SCA by finding that the HOD was empowered to issue an instruction to the principal of a public school to admit a learner in excess of the limit set in its admission policy. ${ }^{134}$

However, the Department's power to override the admissions decision of a school had to be exercised reasonably and in a procedurally fair manner in terms of the requirements of the Promotion of Administrative Justice Act 3 of 2000 (PAJA). ${ }^{135}$ In the present case, these duties of procedural fairness should have included affording the principal an opportunity to address it on factors such as the impact of the proposed admission of the learner on the quality of education of other learners at the school, access to resources for the learner herself, and the time that might be required to accommodate the learner. ${ }^{136}$ This duty arose particularly in the light of the time lapse between the principal's initial reasons offered to the HOD for the rejection of the learner's admission application and the HOD's intervention in terms of the Gauteng regulations, almost 3 months later, when the new school year was already underway. The second consideration in favour of affording the principal a hearing was the fact that at the time of the intervention the tenthday admission statistics of the school had become available. The principal should have been afforded an opportunity to make representations to the department on the HOD's interpretation of these statistics or the implications of the actions contemplated in the light thereof. ${ }^{137}$ Thirdly, the Court was unpersuaded that the consultations held between the department and the

132 MEC for Education v Governing Body of the Rivonia Primary School 20136 SA 582 (CC) paras 21 - 26.

133 MEC for Education v Governing Body of the Rivonia Primary School 20136 SA 582 (CC) paras $35-45$.

134 MEC for Education v Governing Body of the Rivonia Primary School 20136 SA 582 (CC) para 81, Order 3(a).

135 MEC for Education v Governing Body of the Rivonia Primary School 20136 SA 582 (CC) paras $48-68$.

136 MEC for Education v Governing Body of the Rivonia Primary School 20136 SA 582 (CC) para 64.

137 MEC for Education v Governing Body of the Rivonia Primary School 20136 SA 582 (CC) para 65. 
school from September to November of the previous school year satisfied the requirements of procedural fairness. The outcome of these consultations appeared to be that the departmental officials acknowledged the school's position that the learner would have to wait her turn on the waiting list for admission to the school, and the District Director had indicated a willingness to assist with the alternative placement of the learner if her parents were in agreement with this proposal. ${ }^{138}$ The actions of the Department in February of the new school year came as "a rude shock" to the school, which was operating under the impression that the matter had been resolved. ${ }^{139}$ The intervention accordingly violated the prescripts of procedural fairness, given the school's legitimate expectation of a hearing prior to the intervention. ${ }^{140}$

However, the Court went further than upholding a duty of procedural fairness in the circumstances, holding that "the partnership and cooperation framework" envisaged in the Schools Act created additional duties in the context of dealing with systemic capacity constraints in the public schooling system. ${ }^{141}$ It was "the required general norm" that disputes between school governing bodies and national or provincial governments should be resolved through cooperation in order to protect the best interests of learners and the realisation of the right to basic education. ${ }^{142}$ The majority highlighted the critical role of engagement in realising the right to education in the context of systemic capacity issues in public schools. ${ }^{143}$ Planning, coordination and collaboration between all stakeholders was essential for ensuring that there were sufficient school places for all children. Accordingly, a duty of "proper engagement" between all affected parties arose where a provincial department required a school to admit learners in excess of the limits stated in a school's admission policy. ${ }^{144}$ The Court cited the main and concurring judgments in the Welkom High School case in emphasising the significance and purpose of good faith engagement in

138 MEC for Education v Governing Body of the Rivonia Primary School 20136 SA 582 (CC) para 66.

139 MEC for Education v Governing Body of the Rivonia Primary School 20136 SA 582 (CC) para 67.

140 MEC for Education v Governing Body of the Rivonia Primary School 20136 SA 582 (CC) para 68.

141 MEC for Education v Governing Body of the Rivonia Primary School 20136 SA 582 (CC) para 69.

142 MEC for Education v Governing Body of the Rivonia Primary School 20136 SA 582 (CC) para 69.

143 MEC for Education v Governing Body of the Rivonia Primary School 20136 SA 582 (CC) paras $70-71$.

144 MEC for Education v Governing Body of the Rivonia Primary School 20136 SA 582 (CC) para 72. 
education rights disputes. ${ }^{145}$ The majority held that the HOD's actions undermined the engagement which had taken place late in the previous school year. It raised the spectre of high-handed, unilateral intervention in disregard of the roles of school governing bodies within the partnership model of school governance established by the Schools Act. ${ }^{146}$

The governing body's reaction was regarded by the majority as being equally problematic. By resorting to litigation to safeguard its own authority, it failed to place the interests of the learner first. In addition to declaratory relief in respect of its own powers, it also sought relief requiring the learner to be placed in another primary school until she could be accommodated at Rivonia Primary. This relief was sought despite the fact that the admission of one additional learner would not be unduly burdensome. ${ }^{147}$ The Court emphasised that the duty of cooperation to reach an amicable solution was "intimately connected" to the best interests of the child. ${ }^{148}$ The dispute was likely to have had a traumatic effect on a young, vulnerable learner. As the Court noted, the principle of co-operative governance was not only a tool to facilitate smooth inter-governmental relations, but also helped protect the very people whom government serves. ${ }^{149}$ The effective resolution of complex structural problems in the education system impacting on the constitutional rights of learners depended on a joint endeavour to find workable solutions without resorting to court in every skirmish. ${ }^{150}$

Although the Court devoted some ten paragraphs of its judgment to the importance of co-operative governance and good faith engagement in education rights disputes, it made no specific remedial order in respect of this aspect of its judgment. It set aside the order of the Supreme Court of Appeal and replaced it with three declaratory orders confirming:

145 MEC for Education v Governing Body of the Rivonia Primary School 20136 SA 582 (CC) paras $72-73$.

146 MEC for Education v Governing Body of the Rivonia Primary School 20136 SA 582 (CC) para 75.

147 MEC for Education v Governing Body of the Rivonia Primary School 20136 SA 582 (CC) para 76.

148 MEC for Education v Governing Body of the Rivonia Primary School 20136 SA 582 (CC) para 77.

149 MEC for Education v Governing Body of the Rivonia Primary School 20136 SA 582 (CC) para 77.

150 MEC for Education v Governing Body of the Rivonia Primary School 20136 SA 582 (CC) para 78. 
1) that the HOD was empowered to issue an instruction to the principal of the Rivonia Primary School to admit the learner in excess of the limit in its admission policy;

2) in exercising this power the HOD was obliged to act in a procedurally fair manner; and

3) that the HOD had not acted in a procedurally fair manner when he issued instructions to the principal of Rivonia Primary School to admit the learner and when he placed the learner in the school. ${ }^{151}$

Two justices, Jafta and Zondo JJ, dissented and would have upheld the Department's right to instruct the principal to admit the learner. They were of the view that the procedural fairness point was not pleaded nor supported by the established facts. ${ }^{152}$ Similarly they held that the resolution of systemic capacity issues in the school through co-operation and meaningful engagement was not an issue in the relevant pleadings. The sole issue before the Court was whether the HOD had the power to overturn the principal's decision and admit the learner to the school. In this regard, they held that the principle of constitutional supremacy entitled a HOD to override a policy which was inconsistent with the Constitution. ${ }^{153}$ The main judgment's criticisms of the failure of the HOD to engage meaningfully with the school on systemic capacity issues did not form part of the ratio decidendi of the judgment. ${ }^{154}$ However, even in relation to systemic capacity issues, the minority disputed that the department failed to engage and cooperate with the school, describing the various meetings and consultations that were held with the school. ${ }^{155}$ According to the minority, "[f]aced with a contemptuous governing body and an intransigent principal,

151 MEC for Education v Governing Body of the Rivonia Primary School 20136 SA 582 (CC) para 81 . The principles laid down by the majority were subsequently applied by the SCA in upholding the validity of amended regulations promulgated by the MEC, Gauteng Province concerning the admission of learners to public schools (only one regulation was set aside on the grounds of vagueness): Member of the Executive Council for Education, Gauteng v Federation of Governing Bodies for South African Schools [2015] 4 All SA 591 (SCA).

152 MEC for Education v Governing Body of the Rivonia Primary School 20136 SA 582 (CC) paras $105-110$.

153 MEC for Education v Governing Body of the Rivonia Primary School 20136 SA 582 (CC) para 123.

154 MEC for Education v Governing Body of the Rivonia Primary School 20136 SA 582 (CC) paras $111-112$.

155 MEC for Education v Governing Body of the Rivonia Primary School 20136 SA 582 (CC) paras $114-116$. 
it is difficult to imagine that the Head of Department could have acted differently." 156

\subsubsection{Evaluation}

The facts of the Rivonia Primary School case clearly implicated the right to basic education in section 29(1)(a) of the Constitution. Both the majority and minority judgments were unequivocal that both the Constitution and the Schools Act permitted the provincial education department to override a school's refusal to admit a learner even when it would exceed the admission limits set by the governing body of that school. However, as noted above, the majority held that interventions in school admission decisions constitute administrative action and attract the duties of procedural fairness in terms of section 3(1) of the PAJA. The majority failed to clarify how this duty of procedural fairness relates to the duties of meaningful engagement and cooperative governance when dealing with systemic capacity issues in public schools. Moreover, the actual remedial orders dealt only with the duty of procedural fairness. No orders - whether declaratory, mandatory or supervisory - were made in relation to meaningful engagement, despite the main judgment's emphasis placed on its critical role in dealing with education rights disputes. Perhaps it was unnecessary to do so in the circumstances of the particular case. However, if meaningful engagement is a constitutional duty in education rights disputes, as affirmed by the Court in both in the Rivonia Primary School and the Welkom High School cases, one would expect at least a declaratory order on this requirement. Such an order would have given effect to the third remedial principle discussed above relating to a demonstrable link between the constitutional duties found to be infringed and the remedial orders made. ${ }^{157}$

Another possible reason for the Court's failure to make any specific order relating to meaningful engagement is that it considered engagement duties to be subsumed in the orders pertaining to procedural fairness. However, as the Court's own reasoning on the scope of meaningful engagement suggest, the latter constitutes a participatory process between a number of stakeholders, and in the context of public schools gives expression to the partnership model created by the Schools Act. ${ }^{158}$ Its overarching objective is to give effect to the education rights entrenched in section 29 of the

156 MEC for Education v Governing Body of the Rivonia Primary School 20136 SA 582 (CC) para 117.

157 Part 2.3 above.

158 Head of Department, Department of Education, Free State Province $v$ Welkom High School 20142 SA 228 (CC) paras 124, 129, 135 and 152. 
Constitution through a structured process of both dispute resolution and collaborative decision making. As such, it transcends the rights to be notified and to be heard which underpin the rights to procedural fairness enshrined in sections 3 and 4 of PAJA. ${ }^{159}$ If meaningful engagement is to fulfil the broader objectives contemplated by the Court, it should be given teeth through explicit remedial orders.

The majority judgment could also have elaborated in greater detail on the nature and scope of this duty in the specific circumstances of the Rivonia Primary School case. It will be recalled that the minority (despite considering this aspect of the majority judgment to be obiter dicta) were of the view that the Department had taken sufficient steps to co-operate and engage meaningfully with the school. ${ }^{160}$ In contrast, they regarded the school governing body and principal to be in breach of the duties of good faith engagement and cooperation. ${ }^{161}$ Through clarifying what precisely meaningful engagement entails and the mechanisms through which it should occur, better effect would have been given to the second principle concerning substantive reasoning. ${ }^{162}$

The Rivonia Primary School case affirms meaningful engagement as a significant constitutional obligation in the context of education rights litigation. However, despite the emphasis on collaborative governance and meaningful engagement, the judgment fails to develop the potential of collaborative engagement as a remedy to redress the structural barriers facing learners in accessing quality education.

\section{Conclusion}

Currently public schooling for the majority of overwhelmingly poor, black learners in South Africa is of a poor quality, whilst admissions in many wellresourced former Model C schools remain racially skewed. ${ }^{163}$ The legacy of

159 For a nuanced argument in this regard, see Muller 2011 Stell LR $742-758$. On the potential of the meaningful engagement jurisprudence of the Constitutional Court in socio-economic rights cases to promote a more substantive conceptual of procedural fairness in administrative law, see Van der Berg 2013 SAJHR 376 - 398.

160 MEC for Education v Governing Body of the Rivonia Primary School 20136 SA 582 (CC) paras $113-117$.

161 MEC for Education v Governing Body of the Rivonia Primary School 20136 SA 582 (CC) para 117.

162 See part 2.2 above. Compare the detailed elaboration of the nature and objectives of meaningful engagement in eviction cases in the Olivia Road judgment (ftn 21 above).

163 See, for example, Clowes 1995 http://mg.co.za/article/2015-12-02-schools-biasstymies-black-pupils. 
apartheid education is far from being effectively redressed. In the powerful words of Moseneke DCJ:

In an unconcealed design, the Constitution ardently demands that this social unevenness be addressed by a radical transformation of society as a whole and of public education in particular. ${ }^{164}$

The language, gender and admission barriers to quality schooling must surely be critical elements in the constitutional imperative of educational transformation identified by the Deputy Chief Justice. However, as the three cases analysed and evaluated in this article show, there are powerful stakeholders in schools who seek to defend policies that are inconsistent with constitutional rights and values. Provincial education departments' attempts to counter these policies have been set aside because the relevant authorities failed to comply with the procedures laid down in the Schools Act and the procedural fairness obligations of PAJA.

Nevertheless, the Constitutional Court has sought in these cases to reach the underlying substantive issues in these cases by affirming a duty of all stakeholders to cooperate and engage meaningfully with one another. Beyond the virtues of engagement as a dispute-resolution mechanism, it also provides a structured, participatory remedial process for amending policies to give effect to the rights of learners to education on a nondiscriminatory basis. As Sturm and others have noted, participatory remedies are well suited to redressing deeply entrenched patterns of institutional resistance to fundamental change. ${ }^{165}$ Once and for all court orders are likely to be undermined by overt and covert forms of resistance. Engagement remedies have significant potential to promote the adoption of constitutionally compliant education policies through requiring sustained collaboration amongst a broad array of stakeholders in the sector. Collaborative (rather than unilateral, top-down) policy-making is more likely to be perceived to be legitimate by affected stakeholders, thus increasing their prospects of effective implementation over time. Moreover, as Froneman and Skweyiya JJ emphasised in their concurring judgment in the Welkom High School case, sustained communication between the parties

164 Mpumalanga Department of Education v Hoërskool Ermelo 20102 SA 415 (CC) para 47.

165 The literature on democratic experimentalism is particularly rich in illustrating this potential of participatory mechanisms: see Dorf and Sabel 1998 Columbia LR 267473; Sabel and Simon 2004 Harvard LR 1015-1101. 
is critical to protecting the learners' interests in a school governance dispute. ${ }^{166}$

However, the analysis of the three cases demonstrates that the role of meaningful engagement as a remedy remains undeveloped, and its application falls short of the four core principles of remedial efficacy and legitimacy developed in part 2. In Hoërskool Ermelo, the significance of engagement was implicit in the reasoning of the Court in reaching the underlying language and access to education issues, but played no explicit part in the remedial reasoning or orders. In the Welkom High School case, meaningful engagement formed part of both the Court's reasoning and remedial orders. However, it incorporated only a limited range of stakeholders, and there was no follow-up judgment indicating whether the Court was satisfied with the outcome of the engagement process. It is unclear therefore whether the engagement process resulted in revised pregnancy policies which were consistent with the various constitutional obligations described in the main judgment. In the Rivonia Primary School case, cooperation and engagement were again affirmed as constitutional obligation in dealing with systemic capacity issues in schools. However, the majority judgment did not clarify how such engagement relates to obligations of procedural fairness, and did not refer to engagement in its remedial reasoning and orders.

The valuable role which engagement can potentially play as a remedial mechanism in education rights disputes is best appreciated through understanding the different objectives pursued during the merits and remedial phase of a judgment. The merits phase of a judgment is concerned with determining whether not a constitutional violation has been established. As such, it should contain a clear exposition of the normative values and purposes of the relevant rights, and the nature of the duties they impose on the parties. A court should proceed to explain why a party's acts or omissions constitute an infringement of the relevant duties. The court's role at the remedial stage is different as it seeks to devise a remedy which will be effective and legitimate. ${ }^{167}$ In complex, polycentric cases such as those

166 Head of Department, Department of Education, Free State Province $v$ Welkom High School 20142 SA 228 (CC) para 166 - 167.

167 As Sturm (1991) The Georgetown LJ 1445 notes:

"The nature of the court's liability task - interpreting norms and determining parties' responsibility - differs in important respects from the remedial task - implementing these norms in a particular context. We insist on developing uniform, general rules at the liability stage, but recognize that different contexts may require different remedial approaches to implement those norms. The court's role in determining liability does not depend on the 
involving school governance and access to education, there will often be a range of policy choices to be made in giving effect to the relevant rights, and a number of interests to be considered and weighed. ${ }^{168}$ This is where participatory remedies such as engagement have an important and valuable role to play. They respond to separation of powers concerns by counselling judicial restraint in prescribing particular policy solutions, but preserve the court's constitutional role to ensure that the rights violation is effectively remedied. The recruitment of a broad range of stakeholders to participate jointly in (re-)designing and implementing constitutionally-compliant policies generates the information and skills necessary for sustainable solutions and, as argued above, promotes trust and buy-in amongst all affected stakeholders. ${ }^{169}$

Although the role of meaningful engagement has been inconsistent and undeveloped in the cases reviewed, the Constitutional Court has affirmed its important role in resolving systemic educational disputes. This paves the way for the development of meaningful engagement as a fully-fledged participatory remedy in future education rights disputes. ${ }^{170}$ Such remedies constitute powerful vehicles for developing systemic policy reforms capable of advancing access to quality education for all South Africa's children.

\section{Bibliography}

Bishop "Remedies"

Bishop M "Remedies" in Woolman S, Roux T and Bishop M (eds) Constitutional Law of South Africa $2^{\text {nd }}$ ed (Juta Cape Town 2006) ch 9

Chenwi "Democratizing the Socio-economic Rights-Enforcement Process" Chenwi $L$ "Democratizing the Socio-economic Rights-Enforcement Process" in Alviar García H, Klare K and Williams LA (eds) Social and

parties' acceptance and cooperation, as it does in developing and implementing a remedy."

168 Participatory remedies are not necessarily appropriate in all educational rights disputes. Some cases may indicate a clear, unambiguous solution such as, for example, that every child should receive timeously the textbooks prescribed for their grade subjects. See, for example, Minister of Basic Education v Basic Education for All[2016] 1 All SA 369 (SCA). However, even in these cases where there is no broad range of possible policy solutions, participatory structural remedies accompanied by supervisory orders can play an important role in securing the effective implementation of the relevant orders.

169 As Smit and Oosthuizen 2011 SA Journal of Education 69 note: "The deliberative remedies of structured accountability and shared responsibility aim to counteract selfinterested decision-making by emphasising the common interest of all citizens."

170 See in this regard Sturm's model for aligning participatory remedies in public law with general remedial principles: (1991) The Georgetown LJ 1427 - 1446. 
Economic Rights in Theory and Practice: Critical Inquiries (Routledge London 2015) 178-196

Dorf and Sabel 1998 Columbia $L R$

Dorf MC and Sabel CF "A Constitution of Democratic Experimentalism" 1998 Columbia LR 267-473

Fiss 1984 Yale LJ

Fiss O "Against Settlement" 1984 Yale LJ 1073-1090

Froneman 2005 Stell LR

Froneman J "Legal Reasoning and Legal Culture: Our 'Vision' of Law" 2005 Stell LR 3-20

Hoexter Administrative Law in South Africa

Hoexter C Administrative Law in South Africa $2^{\text {nd }}$ ed (Juta Cape Town 2012)

Jamieson et al (eds) South African Child Gauge

Jamieson L et al (eds) South African Child Gauge (Children's Institute, University of Cape Town 2010-2011)

Liebenberg Socio-Economic Rights

Liebenberg S Socio-Economic Rights: Adjudication under a Transformative Constitution (Juta Cape Town 2010)

Liebenberg 2012 AHRLJ

Liebenberg $S$ "Engaging the Paradoxes of the Universal and Particular in Human Rights Adjudication: The Possibilities and Pitfalls of 'Meaningful Engagement"' 2012 AHRLJ 1-29

Liebenberg and Young "Adjudicating Social and Economic Rights: Can Democratic Experimentalism Help?"

Liebenberg S and Young K "Adjudicating Social and Economic Rights: Can Democratic Experimentalism Help?" in Alviar García H, Klare K and Williams LA (eds) Social and Economic Rights in Theory and Practice: Critical Inquiries (Routledge London 2015) 237-257

Mbazira Litigating Socio-Economic Rights

Mbazira C Litigating Socio-Economic Rights: A Choice between Corrective and Distributive Justice (PULP Pretoria 2009)

McConnachie and McConnachie 2012 SALJ

McConnachie $\mathrm{C}$ and McConnachie $\mathrm{C}$ "Concretising the Right to Basic Education" 2012 SALJ 554-590 
Muller 2011 Stell LR

Muller G "Conceptualising 'Meaningful Engagement" as a Deliberative Democratic Partnership" 2011 Stell LR 742-758

Muller and Liebenberg 2013 SAJHR

Muller $\mathrm{G}$ and Liebenberg $S$ "Developing the Law of Joinder in the Context of the Eviction of People from their Homes" 2013 SAJHR 554-570

Mureinik 1994 SAJHR

Mureinik E "A Bridge to Where? Introducing the Interim Bill of Rights" 1994 SAJHR 31-48

Murungi 2015 PER

Murungi LN "Inclusive Basic Education in South Africa: Issues in its Conceptualisation and Implementation" 2015 PER 3160-3195

Nolan Children's Socio-Economic Rights, Democracy and the Courts Nolan A Children's Socio-Economic Rights, Democracy and the Courts (Hart Oxford 2011)

O'Regan 2008 Acta Juridica

O'Regan C "From Form to Substance: The Constitutional Jurisprudence of Laurie Ackermann" 1-17

Sabel and Simon 2004 Harvard LR

Sabel CF and Simon WH "Destabilization Rights: How Public Law Litigation Succeeds" 2004 Harvard LR 1015-1101

Simbo $2012 L D D$

Simbo C "Defining the Term Basic Education in the South African Constitution: An International Law Approach" 2012 LDD 162-184

Smit and Oosthuizen 2011 South African Journal of Education

Smit $\mathrm{MH}$ and Oosthuizen IJ "Improving School Governance through Participative Democracy and the Law" 2011 South African Journal of Education 55-73

Sturm 1991 The Georgetown LJ

Sturm SP "A Normative Theory of Public Law Remedies" 1991 The Georgetown LJ 1355-1446 
Van der Berg 2013 SAJHR

Van der Berg S "Meaningful engagement: Proceduralising socio-economic rights further or infusing administrative law with substance?" 2013 SAJHR 376-398

Woolman The Selfless Constitution

Woolman S The Selfless Constitution: Experimentalism and Flourishing as Foundations of South Africa's Basic Law (Juta Cape Town 2013)

\section{Case law}

AllPay Consolidated Investment Holdings $v$ CEO, SA Social Security Agency (No 2) 20144 SA 179 (CC)

AllPay Consolidated Investment Holdings (Pty) Ltd $v$ Chief Executive Officer of the South African Social Security Agency 20156 BCLR 653 (CC)

Christian Education South Africa v Minister of Education 20004 SA 757 (CC)

City of Johannesburg Metropolitan Municipality v Hlophe [2015] 2 All SA 251 (SCA)

DPP, Transvaal v Minister for Justice and Constitutional Development 2009 4 SA 222 (CC)

Fose v Minister of Safety and Security 19973 SA 786 (CC)

Governing Body of the Juma Musjid Primary School v Essay NO 20118 BCLR 761 (CC)

Head of Department, Department of Education, Free State Province $v$ Welkom High School 20142 SA 228 (CC)

Hoffman $v$ South African Airways 20011 SA 1 (CC)

MEC for Education v Governing Body of the Rivonia Primary School 2013 6 SA $582(\mathrm{CC})$

Member of the Executive Council for Education, Gauteng $v$ Federation of Governing Bodies for South African Schools [2015] 4 All SA 591 (SCA).

Minister of Basic Education v Basic Education for All [2016] 1 All SA 369 (SCA)

Minister of Health v Treatment Action Campaign (No.2) 20025 SA 721 (CC)

Mpumalanga Department of Education v Hoërskool Ermelo 20102 SA 415 (CC) 
National Coalition for Gay and Lesbian Equality v Minister of Home Affairs 20002 SA 1 (CC)

Occupiers of 51 Olivia Road, Berea Township and 197 Main Street Johannesburg $v$ City of Johannesburg 20083 SA 208 (CC)

Pheko v Ekhurhuleni Metropolitan Municipality 20155 SA 600 (CC)

Residents of Joe Slovo Community, Western Cape $v$ Thubelisha Homes 20103 SA 454 (CC)

Residents of Joe Slovo Community, Western Cape $v$ Thubelisha Homes 20117 BCLR 723 (CC)

$S$ v Bhulwana; S v Gwadiso 19961 SA 388 (CC)

Schubart Park Residents Association $v$ City of Tshwane Metropolitan Municipality 20131 SA 323 (CC)

Pheko v Ekhurhuleni Metropolitan Municipality 20122 SA 598 (CC)

\section{Legislation}

Housing Act 107 of 1997

Municipal Systems Act 32 of 2000

Prevention of Illegal Eviction from and Unlawful Occupation of Land Act 19 of 1998

Promotion of Administrative Justice Act 3 of 2000

Promotion of Equality and Prevention of Unfair Discrimination Act 4 of 2000 South African Schools Act 84 of 1996

\section{Internet sources}

Spaull 2012 Poverty and Privilege

Spaull N Poverty \& Privilege: Primary School Inequality in South Africa, Stellenbosch Economic Working Papers: 13/12, University of Stellenbosch and Bureau for Economic Research http://www.ekon.sun.ac.za/ wpapers/2012/wp132012/wp-13-2012.pdf accessed 5 January 2016 Clowes 1995

Clowes A "Schools' Bias Stymies Black Pupils" http://mg.co.za/article/201512-02-schools-bias-stymies-black-pupils accessed 5 January 2016

\section{List of Abbreviations}

AHRLJ African Human Rights Law Journal 
Columbia LR

Harvard LR

HOD

LDD

PAJA

PER

PULP

SCA

SAJHR

SALJ

Stell LR

The Georgetown LJ

Yale LJ
Columbia Law Review

Harvard Law Review

Head of Department

Law, Democracy \& Development

Promotion of Administrative Justice Act

Potchefstroom Electronic Law Journal

Pretoria University Law Press

Supreme Court of Appeal

South African Journal on Human Rights

South African Law Journal

Stellenbosch Law Review

The Georgetown Law Journal

Yale Law Journal 